\author{
Agnieszka Orkusz, Ewa Zając \\ Uniwersytet Ekonomiczny we Wrocławiu \\ e-mail: agnieszka.orkusz@ue.wroc.pl
}

\title{
OCENA WARTOŚCI ENERGETYCZNEJ I ODŻYWCZEJ DIET STOSOWANYCH W ŻYWIENIU PACJENTÓW NA PRZYKŁADZIE WYBRANEGO SZPITALA WIELKOPOLSKI
}

ASSESSMENT OF THE ENERGY AND NUTRITIONAL
VALUES OF DIETS USED IN PATIENTS
ON THE EXAMPLE OF A CHOSEN HOSPITAL
IN GREAT POLAND

DOI: $10.15611 /$ nit.2015.3.03

JEL Classification: I1

Streszczenie: Dieta chorych w szpitalu powinna odpowiadać wysokim standardom żywienia. Jednak żywienie w szpitalach na terenie Polski od lat budzi wiele zastrzeżeń i w wielu przypadkach nie spełnia zasad racjonalnego odżywiania. Celem pracy była ocena wartości energetycznej i odżywczej posiłków serwowanych w szpitalu na podstawie teoretycznej analizy jadłospisów z zastosowaniem programu komputerowego Dieta 4D. Obliczono wartość energetyczną, zawartość: białka, tłuszczu, węglowodanów; składników mineralnych: Ca i Fe, oraz witamin A i C dla 28 całodziennych jadłospisów szpitalnych z czterech pór roku: wiosny, lata, jesieni i zimy. Średnia wartość energetyczna racji kształtowała się na prawidłowym poziomie. Wyniki przeprowadzonych badań wskazują na brak zbilansowania zawartości składników odżywczych w całodziennych racjach pokarmowych pacjentów. W badanych racjach pokarmowych uwidoczniły się nieprawidłowości związane ze zbyt dużą zawartością tłuszczów w stosunku do norm. Poniżej normy w analizowanych jadłospisach szpitalnych była zawartość węglowodanów, wapnia i witaminy C. Powyżej normy w badanych racjach pokarmowych kształtowała się zawartość witaminy A i żelaza. Sugeruje to konieczność edukacji pracowników szpitala w zakresie prawidłowego żywienia pacjentów.

Slowa kluczowe: dieta, szpital, pacjent, zalecenia żywieniowe.

Summary: Patients nutrition in hospital should fulfill high nutrition standards. For many years nutrition in Polish hospitals has risen certain concern, and in many cases it does not fulfill the principles of rational nutrition. The aim of this study was the energetic and nutritional evaluation of meals served in hospital based on a theoretical analysis of the menus using the Diet 4D computer program. The energy values, contents of protein, fat, carbohydrates, mineral ingredients: $\mathrm{Ca}, \mathrm{Fe}$, vitamins: A, C, were calculated for twenty eight hospital menus of four seasons: spring, summer, autumn and winter. The average caloric value of a food ration was 
Agnieszka Orkusz, Ewa Zając

at a correct level. The results of the conducted research indicate lack of balanced content of essential nutrients in patients daily food rations. In the rations incorrectness was found connected with too big - due to the norms - intake of fats. The diet was characterized by low carbohydrates content. The deficient intake in relation to the standards was observed for calcium and vitamin C. High dietary content of vitamin A and iron was found. The results indicate the need for nutritional education of hospital staff.

Keywords: diet, hospital, patient, dietary recommendations.

\section{Wstęp}

Racjonalne żywienie, pokrywające indywidualne zapotrzebowanie na energię i składniki odżywcze, jest warunkiem zachowania optymalnego stanu zdrowia człowieka. Dobór produktów i potraw w większości diet szpitalnych opiera się na zaleceniach diety łatwo strawnej, z której wyłącza się niektóre produkty według wskazań poszczególnych diet.

Dieta chorych w szpitalu powinna odpowiadać wysokim standardom żywienia. Niezbędne są do tego ciągłe upowszechnianie wiedzy na temat zasad racjonalnego żywienia oraz wysoki poziom kwalifikacji zawodowych pracowników odpowiedzialnych za żywienie pacjentów szpitali.

Powszechnie wiadomo, iż jakość żywienia w placówkach szpitalnych, mimo że stanowi integralny element terapii decydującej o wynikach leczenia, jest wysoce niezadowalająca [Turlejska, Pilzner, Konecka-Matyjek 2006; Kozłowska-Wojciechowska 2009; Informacja ... 2009; Grzesińska i in. 2014]. Niedożywienie pacjentów i pogłębianie się tego stanu w trakcie hospitalizacji niekorzystnie wpływa na przebieg leczenia i rekonwalescencję pacjenta, wydłużając jego pobyt w szpitalu. Racjonalna, odpowiednio zbilansowana dieta pozwala na skrócenie czasu hospitalizacji, co pozwala na obniżenie całkowitych kosztów leczenia o 30-50\% [Jarosz (red.) 2011], a nawet do 75\% [Informacja... 2009].

Celem pracy było oszacowanie wartości energetycznej i odżywczej posiłków serwowanych pacjentom w wybranym szpitalu województwa wielkopolskiego na podstawie 7-dniowych jadłospisów w zależności od pory roku.

\section{Materiały i metody badawcze}

Badania polegały na ocenie jadłospisów pochodzących z publicznego zakładu opieki zdrowotnej, w województwie wielkopolskim. Wstępna analiza wykazała stosowanie w szpitalu 7-dniowego systemu układania jadłospisów. W związku z tym ocenie poddano po 7 jadłospisów (losowo wybrany tydzień) stosowanych $\mathrm{w}$ diecie łatwo strawnej, z każdej pory roku.

Przeprowadzono ocenę 28 całodziennych jadłospisów. Jadłospisy pochodziły z roku 2013. Stosując tabele „Produkty spożywcze, skład i wartość odżywcza” oraz 
program komputerowy Dieta 4D (IŻŻ, Warszawa), wyznaczono wartość energetyczną oraz zawartość składników odżywczych, takich jak: białka, tłuszcze, węglowodany, składniki mineralne (wapń, żelazo) oraz witaminy (A, C) w jadłospisach 7-dniowych dla poszczególnych pór roku: wiosny, lata, jesieni i zimy. W obliczeniach uwzględniono straty związane ze stosowanymi procesami technologicznymi. Dla wartości energetycznej, białka ogółem, tłuszczów, węglowodanów, wapnia i żelaza zastosowano straty równe $10 \%$. Ze względu na zróżnicowaną wrażliwość witamin na czynniki występujące podczas obróbki kulinarnej potraw wartości dla witaminy A zredukowano o 20\%, zaś dla witaminy $\mathrm{C}-\mathrm{o} 55 \%$ [Kunachowicz i in. 2005].

Uzyskane wyniki porównano z zaleceniami dotyczącymi żywienia szpitalnego [Jarosz (red.) 2011; Jarosz i in. 2012] oraz ze szczegółowymi zaleceniami dla diety łatwo strawnej [Biernat (red.) 2009; Ciborowska, Rudnicka 2009; Jarosz (red.) 2011]. Zapotrzebowanie na energię i składniki odżywcze dla 96 pacjentów oddziału internistycznego ustalono na podstawie średnioważonej normy żywienia, znając liczbę, płeć oraz wiek osób spożywających dietę łatwo strawną, przy założeniu ich małej aktywności fizycznej.

Obliczenia statystyczne wykonano z użyciem programu Statistica, wersja 10.0 (Statsoft InC., USA). Normalność rozkładu zmiennych weryfikowano testem Shapiro-Wilka. Pozwoliło to na zastosowanie wartości średniej, odchylenia standardowego oraz wykorzystania analizy wariancji jako testu parametrycznego. Do zbadania istotnych różnic między wartościami średnimi zastosowano test Tukeya na poziome istotności $p \leq 0,05$.

\section{Wyniki i ich omówienie}

Posiłki dla pacjentów przygotowywane były na terenie szpitala - w kuchni szpitalnej. Pielęgniarki przewoziły do oddziałów je w wózkach bemarowych, pozwalających zachować właściwą temperaturę dań od momentu ich przygotowania do podania pacjentowi. Spożywanie posiłków odbywało się w salach chorych.

Zgodnie z zasadami prawidłowego żywienia chorych w szpitalach, jadłospisy powinny być planowane na 7 lub 10 dni [Jarosz (red.) 2011; Tokarska, Góźdź, Szalecki 2011; Całyniuk i in. 2011]. Planowanie zestawów żywieniowych na taki okres usprawnia organizację pracy przy sporządzaniu posiłków i zaopatrzeniu oraz przechowywaniu produktów spożywczych [Tokarska, Góźdź, Szalecki 2011].

Analizowane jadłospisy planowane były na $7 \mathrm{dni}$. Stwierdzono, iż w ciągu tego okresu posiłki nie powtarzały się.

Całodzienna racja pokarmowa w szpitalu składała się z trzech posiłków: śniadania, obiadu oraz kolacji. Śniadanie było podawane o godzinie 7:30, obiad - o 12:30, a kolacja - o 17:30. Odstępy między posiłkami były prawidłowe, wynosiły 5 godzin.

Stwierdzono prawidłowy procentowy rozkład energii na posiłki serwowane $\mathrm{w}$ szpitalu w każdej z pór roku (tab. 1). 
Tabela 1. Procentowy rozkład energii [\%] na posiłki serwowane w szpitalu w zależności od pory roku Table 1. Percentage distribution of energy [\%] for the meals served in the hospital depending on the season

\begin{tabular}{|l|c|c|c|c|c|}
\hline $\begin{array}{c}\text { Rodzaj } \\
\text { posiłku } \\
\text { Type of meal }\end{array}$ & $\begin{array}{c}\text { Zalecony/ } \\
\text { Recommended }\end{array}$ & Wiosna/Spring & Lato/Summer & Jesień/Autumn & Zima/Winter \\
\hline $\begin{array}{l}\text { Śniadanie } \\
\text { Breakfast/ }\end{array}$ & $30-35$ & 33,4 & 33,1 & 35,6 & 33,0 \\
\hline $\begin{array}{l}\text { Obiad / } \\
\text { Dinner }\end{array}$ & $35-40$ & 39,3 & 39,6 & 37,3 & 39,4 \\
\hline $\begin{array}{l}\text { Kolacja / } \\
\text { Supper }\end{array}$ & $25-30$ & 27,3 & 27,3 & 27,1 & 27,6 \\
\hline
\end{tabular}

Źródło: opracowanie własne.

Source: own study.

Badane jadłospisy szpitalne nie odpowiadały wszystkim zaleceniom diety łatwo strawnej. Stwierdzono, iż przy przygotowywaniu poszczególnych posiłków stosowano różną technikę sporządzania potraw. Podawano potrawy gotowane, pieczone i duszone, ale także zabronione w diecie łatwo strawnej, smażone i pieczone na tłuszczu (np. kotlet schabowy, smażona kiełbasa, wątroba). Smażenie powoduje, że posiłki są trudno strawne, długo zalegają w żołądku i drażnią przewód pokarmowy [Biernat (red.) 2009]. Nie wykluczono z jadłospisów produktów i potraw thustych (np. kiełbas, serów żółtych i topionych), wzdymających (kapusty kiszonej, kapusty pekińskiej, ogórków, fasoli), konserwowych (ogórki, buraki) oraz ostrych przypraw, tj. musztardy.

$\mathrm{Na}$ śniadania podawano zupy mleczne z: płatkami kukurydzianymi, zbożowymi, ryżem, kaszą manną. Codziennie serwowano również kawę zbożową z mlekiem oraz kanapki z pieczywa żytniego z masłem oraz produktem o wysokiej zawartości białka (wędliny, jaja, twaróg, ser żółty i topiony) lub węglowodanów w postaci dżemu, zwykle truskawkowego. Sporadycznie do śniadania serwowano plasterki pomidora.

Obiad składał się zawsze z dwóch dań: zupy i drugiego dania. Podawano zupy, m.in.: jarzynową, selerową, pomidorową, barszcz, ale także niewskazaną w diecie łatwo strawnej, wzdymającą zupę fasolową. Zupy przygotowywane były na bazie wywaru mięsno-warzywnego, a w okresie wiosenno-letnim wzbogacane były natką pietruszki lub świeżym koperkiem. Dodatkami do zup były kasza manna, lane kluski, makaron.

$\mathrm{Na}$ drugie danie serwowano produkty będące źródłem pełnowartościowego białka, m.in.: mięso, jaja, rzadko ryby, które uzupełniano prawie wyłącznie ziemniakami. Sporadycznie, bez względu na porę roku, zastępowano je makaronem czy ryżem.

Warzywa podawano gotowane (np. marchew, brokuł), surowe (np. surówka $\mathrm{z}$ białej lub kiszonej kapusty) bądź też konserwowe (np. ogórek, burak). Do obiadu podawana była herbata. 
Kolacja była posiłkiem lekkim, podawanym na kilka godzin przed snem. Na kolację, podobnie jak na śniadanie, podawano pieczywo żytnie z masłem oraz produktem wysokobiałkowym (wędliny, jaja, twaróg, ser żółty). Bez względu na porę roku, na kolację nie podawano ani warzyw, ani owoców.

Smak oraz barwa posiłków skomponowane były w sposób kontrastowy. Podczas jednego posiłku nie serwowano dwóch potraw o podobnym charakterze (słodkim, kwaśnym czy podobnej barwie i konsystencji). W ograniczonych ilościach dodawano przyprawy, takie jak zielony koperek, natka pietruszki, nadużywano natomiast soli.

W jadłospisach nie zauważono sezonowości produktów. Bez względu na porę roku, do posiłków nie podawano owoców. Wadą analizowanych jadłospisów było przyrządzanie posiłków, bazując na produktach zabronionych w diecie łatwo strawnej, np. na śniadanie i kolację podawano ser żółty i topiony, thuste wędliny, produkty konserwowe, a na obiad - tłuste, smażone mięso i wędliny $z$ dodatkiem różnych odmian kapusty czy warzyw konserwowanych octem. Serwowano również przeciwwskazane w diecie łatwo strawnej zupy przygotowane na bazie nasion roślin strączkowych (fasola, groch).

W analizowanych jadłospisach szpitalnych nie zauważono istotnych różnic wartości energetycznej posiłków ze względu na porę roku (tab. 2). Wartość energetyczna posiłków wahała się od 1781,3 kcal zimą do 1898,1 kcal wiosną. Średnia wartość energetyczna racji pokarmowych mieściła się w zakresie obowiązujących norm wiosną i latem, a nieznacznie odbiegała jesienią i zimą, biorąc pod uwagę $\pm 10 \%$ dopuszczalne odchylenie od normy.

Uzyskane wyniki są zgodne z tymi, które wykazał raport Najwyższej Izby Kontroli [Informacja... 2009] po dokładnym zbadaniu 12 szpitali publicznych w sześciu województwach i badaniu ankietowym w 125 losowo wybranych szpitalach w całej Polsce. Posiłki w kontrolowanych szpitalach miały odpowiednią wartość energetyczną, natomiast nie zapewniały odpowiedniej wartości odżywczej. Stwierdzono stosowanie niskiej jakości wędlin, niedobory nabiału, owoców i warzyw, nadużywanie soli. Również Kłos i in. [2007] wykazali, iż wartość energetyczna diet stosowanych w żywieniu pacjentów Wojskowego Instytutu Medycznego w Warszawie odpowiadała zalecanym normom.

Oprócz pokrycia zapotrzebowania energetycznego, bardzo ważne jest zachowanie odpowiednich proporcji składników odżywczych w racji pokarmowej. Białka powinny stanowić 10-15\%, tłuszcze - nie więcej niż 25-30\%, a węglowodany - 55-60\% całodziennej energii racji pokarmowej [Biernat (red.) 2009; Jarosz (red.) 2012].

W strukturze energii analizowanych jadłospisów nie stwierdzono istotnych różnic w zależności od pory roku (tab. 3). Wykazano, że procentowy udział energii pochodzącej z węglowodanów i tłuszczów w badanych jadłospisach był nieprawidłowy i plasował się odpowiednio poniżej $(42,7-47,7 \%)$ i powyżej $(39,6-43,2 \%)$ obowiązującej normy. Zaobserwowano, mieszczący się w granicach normy, udział energii pochodzącej z białek (12,7-14,1\%). 
Tabela 2. Wartość energetyczna i zawartość składników odżywczych w jadłospisach szpitalnych w zależności od pory roku

Table 2. Energy value and nutrients content of hospital menus depending on the season

\begin{tabular}{|c|c|c|c|c|c|c|c|c|c|}
\hline \multirow{2}{*}{$\begin{array}{c} \\
\text { Energia } \\
\text { i składniki } \\
\text { odżywcze/ } \\
\text { Energy and } \\
\text { nutrients }\end{array}$} & \multirow[b]{2}{*}{$\begin{array}{l}\text { Norma/ } \\
\text { Norm }\end{array}$} & \multicolumn{2}{|c|}{$\begin{array}{l}\text { Wiosna/ } \\
\text { Spring }\end{array}$} & \multicolumn{2}{|c|}{$\begin{array}{l}\text { Lato/ } \\
\text { Summer }\end{array}$} & \multicolumn{2}{|c|}{$\begin{array}{l}\text { Jesień/ } \\
\text { Autumn }\end{array}$} & \multicolumn{2}{|c|}{$\begin{array}{l}\text { Zima/ } \\
\text { Winter }\end{array}$} \\
\hline & & $\begin{array}{c}\mathrm{X} \\
\pm \mathrm{SD}\end{array}$ & $\begin{array}{c}\text { Realizacja } \\
\text { normy/ } \\
\text { Norm } \\
\text { realization } \\
{[\%]}\end{array}$ & $\begin{array}{c}\mathrm{X} \\
\pm \mathrm{SD}\end{array}$ & $\begin{array}{c}\text { Reali- } \\
\text { zacja } \\
\text { normy/ } \\
\text { Norm re- } \\
\text { alization } \\
{[\%]}\end{array}$ & $\begin{array}{c}\mathrm{X} \\
\pm \mathrm{SD}\end{array}$ & $\begin{array}{l}\text { Reali- } \\
\text { zacja } \\
\text { normy/ } \\
\text { Norm } \\
\text { realiza- } \\
\text { tion [\%] }\end{array}$ & $\begin{array}{c}\mathrm{X} \\
\pm \mathrm{SD}\end{array}$ & $\begin{array}{c}\text { Reali- } \\
\text { zacja } \\
\text { normy } \\
\text { Norm/ } \\
\text { realiza- } \\
\text { tion [\%] }\end{array}$ \\
\hline $\begin{array}{l}\text { Energia (kcal) / } \\
\text { Energy (kcal) }\end{array}$ & 2000,0 & $\begin{array}{l}1898,1 \\
\pm 104,4\end{array}$ & 94,9 & $\begin{array}{l}1880,0 \\
\pm 132,7\end{array}$ & 94,0 & $\begin{array}{l}1786,7 \\
\pm 101,7\end{array}$ & 89,3 & $\begin{array}{l}1781,3 \\
\pm 105,7\end{array}$ & 89,1 \\
\hline $\begin{array}{l}\text { Białko ogółem }(\mathrm{g}) / \\
\text { Total protein }(\mathrm{g})\end{array}$ & 60,0 & $\begin{array}{l}64,6 \\
\pm 8,8\end{array}$ & 107,6 & $\begin{array}{l}60,4 \\
\pm 8,9\end{array}$ & 96,7 & $\begin{array}{l}58,9 \\
\pm 7,4\end{array}$ & 98,1 & $\begin{array}{l}56,7 \\
\pm 7,4\end{array}$ & 94,5 \\
\hline $\begin{array}{l}\text { Thuszcz }(\mathrm{g}) / \\
\text { Fat }(\mathrm{g})\end{array}$ & 66,7 & $\begin{array}{l}89,9 \\
\pm 9,2\end{array}$ & 134,7 & $\begin{array}{c}85,1 \\
\pm 11,1\end{array}$ & 127,7 & $\begin{array}{r}80,9 \\
\pm 18,2\end{array}$ & 121,1 & $\begin{array}{l}78,3 \\
\pm 9,5\end{array}$ & 117,4 \\
\hline $\begin{array}{l}\text { Węglowodany } \\
\text { ogółem (g)/ } \\
\text { Total } \\
\text { carbohydrates (g) }\end{array}$ & 275,0 & $\begin{array}{l}207,7 \\
\pm 11,9\end{array}$ & 75,5 & $\begin{array}{l}218,4 \\
\pm 24,2\end{array}$ & 79,4 & $\begin{array}{l}207,0 \\
\pm 13,2\end{array}$ & 75,3 & $\begin{array}{l}212,2 \\
\pm 19,0\end{array}$ & 77,1 \\
\hline $\begin{array}{l}\text { Wapń (mg) / } \\
\text { Calcium (mg) }\end{array}$ & 700,0 & $\begin{array}{l}480,0 \\
\pm 33,4\end{array}$ & 68,6 & $\begin{array}{l}500,0 \\
\pm 54,3\end{array}$ & 71,4 & $\begin{array}{l}430,0 \\
\pm 52,2\end{array}$ & 61,0 & $\begin{array}{l}490,0 \\
\pm 59,5\end{array}$ & 70,0 \\
\hline $\begin{array}{l}\text { Żelazo (mg) / } \\
\text { Iron (mg) }\end{array}$ & 11,0 & $\begin{array}{l}16,9 \\
\pm 2,9\end{array}$ & 153,3 & $\begin{array}{l}13,9 \\
\pm 2,6\end{array}$ & 126,0 & $\begin{array}{l}12,1 \\
\pm 1,8\end{array}$ & 110,36 & $\begin{array}{l}11,6 \\
\pm 2,7\end{array}$ & 105,2 \\
\hline $\begin{array}{l}\text { Witamina } \mathrm{A}(\mu \mathrm{g}) / \\
\text { Vitamin } \mathrm{A}(\mu \mathrm{g})\end{array}$ & 800,0 & $\begin{array}{l}1672,7^{\mathrm{a}} \\
\pm 124,3\end{array}$ & 209,1 & $\begin{array}{l}856,9^{b} \\
\pm 117,5\end{array}$ & 107,1 & $\begin{array}{l}859,1^{\mathrm{b}} \\
\pm 119,4\end{array}$ & 107,4 & $\begin{array}{r}974,3^{\mathrm{b}} \\
\pm 118,7\end{array}$ & 121,8 \\
\hline $\begin{array}{l}\text { Witamina C (mg) / } \\
\text { Vitamin C (mg) }\end{array}$ & 82,0 & $\begin{array}{l}80,3^{\mathrm{a}} \\
\pm 8,1\end{array}$ & 97,9 & $\begin{array}{l}79,4^{\mathrm{a}} \\
\pm 7,5\end{array}$ & 96,9 & $\begin{array}{l}64,9^{\mathrm{b}} \\
\pm 7,3\end{array}$ & 79,1 & $\begin{array}{l}83,3^{\mathrm{a}} \\
\pm 8,9\end{array}$ & 101,6 \\
\hline
\end{tabular}

Objaśnienia: / Explanatory notes:

$\mathrm{X}$ - wartość średnia z 7 jadłospisów / X - the average value of 7 menus.

$\mathrm{SD}$ - odchylenie standardowe / SD - standard deviation.

$\mathrm{a}, \mathrm{b}$ - różne litery w wierszu oznaczają statystycznie istotną różnicę pomiędzy wartościami średni$\mathrm{mi}(p \leq 0,05) / \mathrm{a}, \mathrm{b}-$ various letters in a row denote a statistically significant difference between mean values $(p \leq 0.05)$.

Źródło: opracowanie własne.

Source: own study.

W analizowanych jadłospisach szpitalnych całkowita zawartość białka nie różniła się istotnie w zależności od pory roku i mieściła się w granicach zalecanej normy w każdej z pór roku (tab. 2). Prawidłowa zawartość białka ma szczególne znaczenie w przypadku pacjentów przebywających w szpitalu, ponieważ białka odpowiedzialne są m.in. za obronę organizmu przed działaniem drobnoustrojów i wirusów, decydują o regeneracji wydalanych lub uszkodzonych tkanek [Ho i in. 2008]. Odpowiednia ilość białka $\mathrm{w}$ analizowanych jadłospisach szpitalnych ma istotne znaczenie przy stwierdzonej zbyt niskiej podaży wapnia (tab. 3), ponieważ dieta bogata w białka sprzyja wydalaniu wapnia z moczem. 
Tabela 3. Procentowy udział energii z białek, tłuszczów i węglowodanów w jadłospisach szpitalnych w zależności od pory roku

Table 3. Percentage of the energy from protein, fat and carbohydrates in hospital menus depending on the season

\begin{tabular}{|l|c|c|c|c|}
\hline $\begin{array}{c}\text { Udział energii z:/ } \\
\text { Energy percent from: }\end{array}$ & $\begin{array}{c}\text { Wiosna/ } \\
\text { Spring }\end{array}$ & $\begin{array}{c}\text { Lato/ } \\
\text { SummeR }\end{array}$ & $\begin{array}{c}\text { Jesień/ } \\
\text { Autumn }\end{array}$ & $\begin{array}{c}\text { Zima/ } \\
\text { Winter }\end{array}$ \\
\hline Białek / Proteins & 14,1 & 12,9 & 13,2 & 12,7 \\
\hline Tłuszczów / Fats & 43,2 & 40,9 & 40,6 & 39,6 \\
\hline Węglowodanów / Carbohydrates & 42,7 & 46,2 & 46,2 & 47,7 \\
\hline
\end{tabular}

Źródło: opracowanie własne.

Source: own study.

Zawartość tłuszczów w analizowanych jadłospisach nie różniła się w zależności od pory roku (tab. 2). Stwierdzono zbyt wysoką zawartość tłuszczów ogółem w analizowanych racjach pokarmowych, która wahała się od 78,3 g zimą do 89,9 g wiosną (tab. 2). Zbyt duża zawartość tłuszczu w żywieniu człowieka sprzyja nadwadze i otyłości [Arslan, Kiziltan 2010] może powodować choroby układu krążenia, miażdżycę, a także może przyczyniać się do rozwoju niektórych schorzeń nowotworowych [Ciborowska, Rudnicka 2009]. Należy zauważyć, iż nadmiar tłuszczów zmniejsza absorpcję wapnia, którego zawartość w badanych racjach pokarmowych i tak była za niska w stosunku do zaleceń (tab. 2). Również Pokrzywa i Cieślik [2008], Całyniuk i in. [2011] oraz Kardasz i Ostrowska [2012] odnotowali zbyt wysoką podaż tłuszczu w posiłkach szpitalnych.

Zawartość węglowodanów w analizowanych racjach szpitalnych nie różniła się istotnie w zależności od pory roku i wahała się od 207,0 g jesienią do 218,4 g latem, co odpowiadało pokryciu normy w zakresie $75,3-79,4 \%$ (tab. 2). Niedobór węglowodanów w dietach pacjentów odnotowano również w badaniach innych autorów [Małgorzewicz i in. 2004; Pokrzywa, Cieślik 2008; Sahin i in. 2009].

Zawartość składników mineralnych: wapnia i żelaza oraz witaminy $\mathrm{C}$ nie różniła się istotnie $\mathrm{w}$ zależności od pory roku (tab. 2). Jadłospisy szpitalne w różnym stopniu, w stosunku do zalecanych norm, pokrywały zapotrzebowanie pacjentów na wapń, żelazo, witaminy A i C. Poniżej normy w analizowanych racjach pokarmowych była zawartość zarówno wapnia w każdej z pór roku, jak i witaminy $\mathrm{C}$ jesienią (tab. 2).

Zapotrzebowanie na wapń zostało pokryte w wysokości od $61,0 \%$ jesienią do 71,4\% latem (tab. 2). Zbyt niska podaż wapnia w diecie jest zjawiskiem niekorzystnym, ponieważ prowadzi do zmiękczenia i deformacji kości [Marcinowska-Suchowierska 2001; Misiorowski 2004]. Niedobór wapnia jest szczególnie niebezpieczny dla kobiet, u których utrata masy kostnej z wiekiem jest znacznie większa aniżeli u mężczyzn na skutek zmniejszenia się poziomu estrogenów po menopauzie [Berg 2003]. Zbyt małe spożycie wapnia w diecie wpływa także na rozwój chorób układu 
sercowo-naczyniowego [Bolesławska i in. 2009], może zwiększać ryzyko udaru mózgu u kobiet w średnim wieku [Elders i in. 1994].

Również inni autorzy informują o niewystarczającej ilości wapnia w dietach szpitalnych [Figurska-Ciura 2004; Pokrzywa i Cieślik 2008]. Jak donoszą Orkusz i Włodarczyk [2014], za Przysiężną i in. [2002], zbyt małą podaż wapnia stwierdza się w żywieniu różnych grup ludności, bez względu na sposób oznaczania (obliczeniowo czy analitycznie), jak i materiał stanowiący podstawę oceny zawartości tego składnika mineralnego (wywiady żywieniowe, raporty magazynowe czy też racje pokarmowe odtworzone w laboratorium).

Zawartość witaminy $\mathrm{C}$ w analizowanych jadłospisach różniła się $\mathrm{w}$ zależności od pory roku (tab. 2). Niewystarczające pokrycie zapotrzebowania na witaminę $\mathrm{C}$ stwierdzono wyłącznie jesienią, kiedy to szczególnie ważna jest odpowiednia podaż tej witaminy. Niedobór witaminy $\mathrm{C}$ odpowiedzialny jest za większą skłonność do infekcji, potęgowanie powstawania zmian miażdżycowych [Stefańska i in. 2009]. Wiadomo również, że witaminy antyoksydacyjne, w tym witamina $\mathrm{C}$, ograniczają również ryzyko chorób nowotworowych [Grajek 2004]. Najwyższą ilość kwasu askorbinowego wykazano w badanych jadłospisach zimą, stwierdzając w nich równocześnie najwyższą podaż warzyw i owoców bogatych w witaminę C (tab. 4).

Zbyt niską zawartość witaminy $\mathrm{C}$ w dietach szpitalnych wykazały badania Figurskiej-Ciury i in. [Figurska-Ciura, Brzezińska, Żechałko-Czajkowska 2004], Pysz i in. [Pysz, Pisulewski, Tokarska 2004] oraz Całyniuk i in. [2011].

Zawartość żelaza w jadłospisach szpitalnych mieściła się w zakresie obowiązujących norm jesienią i zimą, natomiast w okresie wiosenno-letnim była wyższa od zalecanej normy (tab. 2). Nadmiar żelaza wiosną związany był ze zwiększoną w tym okresie podażą mięsa i wędlin, a latem dodatkowo jaj (tab. 4). Znaczne przekroczenie zaleceń żelaza wiosną wiązało się z serwowaniem w posiłkach szpitalnych wątróbki drobiowej, co miało też wpływ na przekroczenie w tym sezonie zaleceń na witaminę A (tab. 2). Wyniki badań własnych odbiegają od wyników innych autorów, którzy stwierdzili brak pokrycia zapotrzebowania na żelazo w dietach szpitalnych [Figurska-Ciura, Brzezińska, Żechałko-Czajkowska 2004; Pokrzywa, Cieślik 2008; Całyniuk i in. 2011].

Powyżej normy w analizowanych jadłospisach kształtowała się zawartość witaminy A wiosną i zimą. Zawartość witaminy A wiosną wynosiła $1672,7 \mu \mathrm{g}$, a zimą $974,3 \mu \mathrm{g}$, wartości te stanowily odpowiednio $209,1 \%$ i $121,8 \%$ zalecanej normy (tab. 2). Nadmierna podaż witaminy A jest toksyczna dla organizmu, może przejawiać się m.in.: bólem głowy, drażliwością, wymiotami, zmianami skórnym. Duże dawki witaminy A powodują ubytek wapnia z kości, co prowadzi m.in. do redukcji gęstości kości i łatwości ich złamań, a w konsekwencji - do osteoporozy [Peckenpaugh 2011]. Dane literaturowe potwierdzają nadmierne pobranie w stosunku do norm ilości witaminy A przez pacjentów placówek służby zdrowia [Pokrzywa, Cieślik 2008; Pysz-Izdebska i in. 2010; Całyniuk i in. 2011]. 
Analizując zawartość grup produktów spożywczych w jadłospisach szpitalnych w zależności od pory roku, istotne różnice stwierdzono w grupie: jaja; mięso, wędliny, ryby; masło; ziemniaki; warzywa i owoce bogate w witaminę $\mathrm{C}$; inne warzywa i owoce; strączkowe suche oraz cukier (tab. 4). Wiosną, w porównaniu z pozostałymi porami roku, odnotowano najwyższą podaż mięsa, wędlin i ryb, konsekwencją czego była najwyższa zawartość tłuszczu w tym sezonie i przekroczenie normy na tłuszcz o 34,7\% (tab. 2). Zaobserwowano bowiem, iż podawano wędliny niskiej

Tabela 4. Zawartość 12 grup produktów w jadłospisach pacjentów w zależności od pory roku [g] Table 4. The content of 12 groups of food products in patients menus depending on the season [g]

\begin{tabular}{|l|c|c|c|c|c|c|c|c|}
\hline $\begin{array}{l}\text { Grupa produktów spożywczych/ } \\
\text { Group of products }\end{array}$ & $\begin{array}{c}\text { Wiosna/ } \\
\text { X }\end{array}$ & $\begin{array}{c}\text { Spring } \\
\text { SD }\end{array}$ & $\begin{array}{c}\text { Lato/ } \\
\text { X }\end{array}$ & $\begin{array}{c}\text { Summer } \\
\text { SD }\end{array}$ & $\begin{array}{c}\text { Jesień/ } \\
\text { X }\end{array}$ & $\begin{array}{c}\text { Autumn } \\
\text { SD }\end{array}$ & $\begin{array}{c}\text { Zima/ } \\
\text { X }\end{array}$ & $\begin{array}{c}\text { Winter } \\
\text { SD }\end{array}$ \\
\hline $\begin{array}{l}\text { Produkty zbożowe } \\
\text { Cereal products }\end{array}$ & 192,6 & 28,5 & 207,7 & 34,3 & 207,4 & 31,5 & 191,6 & 27,2 \\
\hline $\begin{array}{l}\text { Mleko i produkty mleczne } \\
\text { Milk and milk products }\end{array}$ & 346,4 & 36,9 & 386,5 & 37,6 & 394,8 & 41,6 & 335,1 & 35,1 \\
\hline $\begin{array}{l}\text { Jaja } \\
\text { Eggs }\end{array}$ & $12,1^{\mathrm{ab}}$ & 1,8 & $47,1^{\mathrm{c}}$ & 4,2 & $9,8^{\mathrm{a}}$ & 1,6 & $18,9^{\mathrm{b}}$ & 2,8 \\
\hline $\begin{array}{l}\text { Mięso, wędliny, ryby } \\
\text { Meat, charcuterie, fish }\end{array}$ & $214,0^{\mathrm{a}}$ & 27,4 & $154,2^{\mathrm{b}}$ & 23,9 & $183,7^{\mathrm{b}}$ & 28,7 & $158,9^{\mathrm{b}}$ & 21,1 \\
\hline $\begin{array}{l}\text { Masło } \\
\text { Butter }\end{array}$ & $4,3^{\mathrm{a}}$ & 0,4 & $6,6^{\mathrm{b}}$ & 1,3 & $3,5^{\mathrm{a}}$ & 0,7 & $6,8^{\mathrm{b}}$ & 0,9 \\
\hline $\begin{array}{l}\text { Inne tłuszcze } \\
\text { Other fats }\end{array}$ & $45,4^{\mathrm{a}}$ & 3,8 & 42,4 & 2,4 & 43,5 & 3,3 & 41,7 & 3,4 \\
\hline $\begin{array}{l}\text { Ziemniaki } \\
\text { Potatoes }\end{array}$ & $374,9^{\mathrm{a}}$ & 31,6 & $314,1^{\mathrm{ab}}$ & 29,2 & $267,3^{\mathrm{b}}$ & 37,3 & $287,3^{\mathrm{b}}$ & 29,3 \\
\hline $\begin{array}{l}\text { Warzywa i owoce (witamina C) } \\
\text { Vegetables and fruit (vitamin C) }\end{array}$ & $78,4^{\mathrm{a}}$ & 13,2 & $68,0^{\mathrm{a}}$ & 16,7 & $78,0^{\mathrm{a}}$ & 18,0 & $113,9^{\mathrm{b}}$ & 19,7 \\
\hline $\begin{array}{l}\text { Warzywa i owoce (karoten) } \\
\text { Vegetables and fruit (carotene) }\end{array}$ & $57,6^{2}$ & 4,5 & 65,2 & 6,0 & 60,4 & 11,8 & 73,3 & 13,3 \\
\hline $\begin{array}{l}\text { Inne warzywa i owoce } \\
\text { Other vegetables and fruit }\end{array}$ & $51,3^{\mathrm{a}}$ & 7,3 & $126,1^{\mathrm{b}}$ & 24,7 & $69,8^{\mathrm{a}}$ & 19,1 & $82,1^{\mathrm{a}}$ & 14,6 \\
\hline $\begin{array}{l}\text { Strączkowe suche } \\
\text { Legumes }\end{array}$ & $4,6^{\mathrm{a}}$ & 1,7 & $1,8^{\mathrm{b}}$ & 0,9 & $6,4^{\mathrm{a}}$ & 1,3 & $6,4^{\mathrm{a}}$ & 0,8 \\
\hline $\begin{array}{l}\text { Cukier } \\
\text { Sugar }\end{array}$ & $3,3^{\mathrm{a}}$ & 0,8 & $11,4^{\mathrm{b}}$ & 2,1 & $4,0^{\mathrm{a}}$ & 0,3 & $11,8^{\mathrm{b}}$ & 1,6 \\
\hline
\end{tabular}

Objaśnienia: / Explanatory notes:

$\mathrm{X}$ - wartość średnia z 7 jadłospisów / $\mathrm{X}$ - the average value of 7 menus.

$\mathrm{SD}$ - odchylenie standardowe / SD - standard deviation.

$\mathrm{a}, \mathrm{b}, \mathrm{c}$ - różne litery w wierszu oznaczają statystycznie istotną różnicę pomiędzy wartościami średnimi $(p \leq 0,05)$ / a , b , c - various letters in a row denote a statistically significant difference between mean values $(p \leq 0.05)$.

Źródło: opracowanie własne.

Source: own study. 
jakości, o dużej zawartości tłuszczu, np. parówki, serdelki. Zimą, w porównaniu z pozostałymi porami roku, podawano najwięcej owoców i warzyw bogatych w witaminę C. Niższą w pozostałych porach roku podaż owoców i warzyw bogatych w witaminę $\mathrm{C}$ trudno wytłumaczyć ze względu na obfitość, zwłaszcza w sezonie letnim i jesiennym, tych produktów, kiedy ich cena jest niska.

Z jadłospisów należy wyeliminować grupę „strączkowe suche”, które powinny być wyłączone $z$ diety łatwo strawnej.

Wykazane odchylenia od norm spożycia składników odżywczych w analizowanych jadłospisach mogą niekorzystnie wpływać na skuteczność leczenia i czas rekonwalescencji pacjentów szpitala. Nieprawidłowości zaobserwowane w analizowanych jadłospisach potwierdzają konieczność ciągłego upowszechniania wiedzy na temat zasad racjonalnego żywienia, także wśród dietetyków w szpitalach.

\section{Wnioski}

1. W badanych jadłospisach stwierdzono nieprawidłowości w sposobie żywienia pacjentów w szpitalu w zakresie zbyt wysokiego w stosunku do zalecanych norm spożycia tłuszczów i zbyt niskiego spożycia węglowodanów.

2. Racje pokarmowe były dobrze zbilansowane pod względem wartości energetycznej i zawartości białka.

3. Analizowane jadłospisy w różnym stopniu zaspokajały zapotrzebowanie pacjentów na składniki mineralne - wapń i żelazo oraz witaminę A i C:

- poniżej normy w badanych jadłospisach szpitalnych była zawartość wapnia w każdej z pór roku, jak i witaminy $\mathrm{C}$ jesienią;

- powyżej normy w analizowanych racjach pokarmowych kształtowała się zawartość witaminy A wiosną i zimą oraz zawartość żelaza wiosną i latem.

4. Badane jadłospisy szpitalne nie odpowiadały zaleceniom diety łatwo strawnej. Serwowano produkty i potrawy smażone, tłuste (np. kiełbasy, sery żółte i topione), wzdymające (np. kapusta kiszona, fasola), konserwowe (ogórki, buraki) oraz ostre przyprawy (musztarda).

5. Przeprowadzona ocena szpitalnych racji pokarmowych wskazuje na konieczność modyfikacji ich składu oraz edukację osób odpowiedzialnych za żywienie pacjentów.

\section{Literatura}

Arslan Y., Kiziltan G., 2010, Nutrition-related cardiovascular risk factors in hemodialysis patients, Journal of Renal Nutrition, 20, s. 185-192.

Berg A.O., 2003, Screening for osteoporosis in postmenopausal women: recommendations and rationale, American Journal of Nursing, 103 (1), s. 73-80.

Biernat J. (red.), 2009, Wybrane zagadnienia z nauki o żywieniu człowieka, Wydawnictwo Uniwersytetu Przyrodniczego we Wrocławiu. 
Bolesławska I., Przysławski J., Schlegel-Zawadzka M., Grzymisławski M., 2009, Zawartość składników mineralnych $w$ całodziennych racjach pokarmowych kobiet i mężczyzn stosujących dietę tradycyjnq i „optymalną” - analiza porównawcza, Żywność. Nauka. Technologia. Jakość, 4 (65), s. 303-311.

Całyniuk B., Grochowska-Niedworok E., Misiarz M., Podniesińska R., 2011, Ocena wartości energetycznej $i$ odżywczej diet na przykładzie wybranego szpitala województwa śląkiego, Bromatologia i Chemia Toksykologiczna, XLIV, 3, s. 434-441.

Ciborowska H., Rudnicka A., 2009, Dietetyka. Żywienie zdrowego i chorego człowieka, Wydawnictwo Lekarskie PZWL, Warszawa.

Elders P.J., Lips P., Netelenbos J.C., Van Ginkel F.C, Khoe E., Van der Vijgh W.J., Van der Stelt P.F., 1994, Long-term effect of calcium supplementation on bone loss in perimenopausal women, Journal of Bone and Mineral Research, 9, s. 963-970.

Figurska-Ciura D., Brzezińska A., Żechałko-Czajkowska A., 2004, Ocena wartości odżywczej diet szpitalnych, Materiały VI Krajowych Warsztatów Żywieniowych, Kraków.

Grajek W., 2004, Rola przeciwutleniaczy w zmniejszaniu ryzyka wystapienia nowotworów i chorób układu krążenia, Żywność. Nauka. Technologia. Jakość, 1 (38), s. 3-11.

Grzesińska W., Tomaszewska M., Bilska B., Trafiałek J., 2014, Optymalizacja uwarunkowań wyboru systemu dystrybucji posiłków w żywieniu szpitalnym, Żywność. Nauka. Technologia. Jakość, 4 (95), s. 188-200.

Ho L., Wang H.H., Peng Y.S., Chiang C.K., Huang J.W., Hung K.Y., Hu F.C., Hu K.D., 2008, Clinical uutility of malnutrition-inflammation score in maintenance hemodialysis patients: Focus on identifying the best cut - off point, American Journal of Nephrology, 28, s. 840-846.

Informacja o wynikach kontroli żywienia $i$ utrzymania czystości $w$ szpitalach publicznych, 2009, www.nik.gov.pl/plik/id,95,vp,95.pdf.

Jarosz M. (red.), 2011, Zasady prawidłowego żywienia chorych w szpitalach, Wydawnictwo Instytutu Żywności i Żywienia, Warszawa.

Jarosz M., Respondek W., Wolnicka K., Sajór I., Wierzejska R., 2012, Zalecenia dotyczace żywienia i aktywności fizycznej, [w:] Normy żywienia dla populacji polskiej - nowelizacja, red. M. Jarosz, Wydawnictwo Instytutu Żywności i Żywienia, Warszawa.

Kardasz M., Ostrowska L., 2012, Ocena sposobu żywienia pacjentów hemodializowanych o zróżnicowanym stopniu odżywienia, Roczniki Państwowego Zakładu Higieny, 63, 4, s. 463-468.

Kłos K., Bertrandt J., Jałocha Ł., Matuszewski T., Abramowicz M., 2007, Wartość energetyczna i odżywcza diet stosowanych $w$ żywieniu i ich ocena przez pacjentów wybranego oddziału klinicznego w Wojskowym Instytucie Medycznym w Warszawie, Roczniki Państwowego Zakładu Higieny, 58,1 , s. 267-271.

Kozłowska-Wojciechowska M., 2009, Praktyczne wskazówki do żywienia człowieka chorego, [w:] Żywienie człowieka zdrowego i chorego, PWN, Warszawa.

Kunachowicz H., Nadolna I., Przygoda B., Iwanow K., 2005, Tabele składu i wartości odżywczej żywności, Wydawnictwo PZWL, Warszawa.

Małgorzewicz S., Lichodziejewska-Niemierko M., Rutkowski R., Łysiak-Szydłowska W., 2004, Ocena sposobu żywienia pacjentów z przewlekta niewydolnościa nerek w okresie leczenia nerkozastępczego, Żywienie Człowieka i Metabolizm, 31, 3, s. 211-218.

Marcinowska-Suchowierska E., 2001, Miejsce wapnia i witaminy D, Przewodnik Lekarski, 4, 4, s. 34-41.

Misiorowski W., 2004, Rola wapnia oraz witaminy D i jej aktywnych metabolitów, Przewodnik Lekarski, 10, s. 97-101.

Orkusz A., Włodarczyk A., 2014, Ocena żywienia dzieci w wieku przedszkolnym na podstawie jadłospisów, Nauki Inżynierskie i Technologie, 1 (12), s. 72-81.

Peckenpaugh N.J., 2011, Podstawy żywienia i dietoterapia, red. wyd. polskiego D. Gajewska, Elsevier Urban \& Partner, Wrocław. 
Pokrzywa P., Cieślik A., 2008, Ocena sposobu żywienia pacjentów w szpitalach województwa małopolskiego, Żywność. Nauka. Technologia Jakość, 1 (56), s. 138-145.

Przysiężna E., Klisz P., Orkusz A., 2002, Oszacowanie zawartości składników mineralnych w racjach pokarmowych młodzieży szkolnej, Żywność. Nauka. Technologia. Jakość, 1 (30), s. 132-140.

Pysz M., Pisulewski P.M., Tokarska A., 2004, Ocena sposobu żywienia pacjentów w Świętokrzyskim Centrum Onkologii, Materiały VI Krajowych Warsztatów Żywieniowych, Kraków, s. 46-47.

Pysz-Izdebska K., Leszczyńska T., Kopeć A., Nowacka E., Bugaj B., 2010, Pokrycie zapotrzebowania na energie $i$ wybrane składniki odżywcze $w$ diecie pensjonariuszy domu pomocy społecznej oraz ocena ich parametrów antropometrycznych, Żywność. Nauka. Technologia. Jakość, 6 (73), s. 239-254.

Sahin H., Ỳnanc N., Katrancỳ D., Aslan N. O., 2009, Is there a correlation between subjective global assessment and food intake, anthropometric measurement and biochemical parameters in nutritional assessment of haemodialysis patients?, Pakistan Journal Medical Sciences, 25, 2, s. 201-206.

Stefańska E., Ostrowska L., Czapska D., Karczewski J., 2009, Ocena zawartości witamin w całodziennych racjach pokarmowych kobiet o prawidłowej masie ciała oraz z nadwaga i otyłościa, Żywność. Nauka. Technologia. Jakość, 4 (65), s. 286-294.

Tokarska A., Góźdź S., Szalecki M., 2011, Charakterystyka żywienia dietetycznego pacjentów świętokrzyskiego centrum onkologii, Studia Medyczne, 23 (3), s. 81-86.

Turlejska H., Pilzner U., Konecka-Matyjek E., 2006, Rola i znaczenie systemu HACCP w żywieniu zbiorowym w szpitalach, Zdrowie Publiczne, 116 (1), s. 152-156. 